\title{
PENGETAHUAN MASYARAKAT DESA TENTANG KESETARAAN GENDER
}

\author{
Oleh : \\ Resti Fauziah, Nandang Mulyana, \& Santoso Tri Raharjo \\ Email: \\ (resfauziah@gmail.com; mulyananandang@gmail.com; santosotriraharjo@gmail.com)
}

\begin{abstract}
ABSTRAK:
Pengetahuan Masyarakat Desa tentang Kesetaraan Gender. Isu kesetaraan gender mulai merebak di Indonesia pada tahun 1990-an. Walaupun isu gender telah lama merebak di Indonesia, namun banyak orang yang masih salah mengartikan tentang konsep gender dan kesetaraan gender. Selain gender yang sering disamakan dengan arti seks (jenis kelamin), kemudian salah arti lainnya dimana kesetaraan gender seolah-olah dianggap sebagai tindakan atau keinginan menomorsatukan perempuan yang ada di belahan dunia. Sebuah penelitian pada kelompok perempuan petani pedesaan di Jambi mengungkapkan bahwa pada awalnya masyarakat setempat sangat risih berbicara dengan kesetaraan gender.Mereka beranggapan bahwa kesetaraan gender adalah hal yang tidak lazim dibicarakan, terlalu vulgar dan mendukung aliran liberalisasi serta sekularitas. Penulis memandang kesetaraan gender ini dapat dijunjung tinggi melalui perubahan pola pikir masyarakat yang berkembang saat ini. Pola pikir yang positif tentang kesetaraan gender akan membantu mengurangi kasus-kasus ketimpangan gender di Indonesia. Mengubah pola pikir masyarakat tentunya harus didasarkan pada pengetahuan masyarakat di daerah itu sendiri.Pekerja sosial khususnya bidang pekerja sosial feminis bertugas untuk mengubah pola pikir dan mengedukasi masyarakat baik kaum laki-laki maupun perempuan.Inti dari artikel ini bahwa masyarakat khususnya masyarakat pedesaan memerlukan tambahan pengetahuan tentang kesetaraan gender. Pemahaman tentang kesetaraan gender yang positif pada masyarakat memiliki banyak manfaatnya dalam kehidupan terutama untuk mengurangi kasus-kasus ketidakadilan gender dan permasalahan rumah tangga. Adapun yang menjadi dasar bagi pekerja sosial dalam melakukan intervensi ialah pendidikan, umur, dan sumber informasi di suatu daerah atau masyarakat tersebut.
\end{abstract}

Kata Kunci : Kesetaraan Gender, Pengetahuan, Masyarakat Desa.

\section{PENDAHULUAN}

Kesetaraan gender merupakan salah satu isu yang menarik untuk diperbincangkan apabila menilik pro kontra yang kerap melekat pada isu ini.Isu kesetaraan gender mulai merebak di Indonesia pada tahun 1990-an. Secara perlahan, gerakan feminisme di Indonesia ini menuntut pergeseran posisi kaum perempuan ke tempat yang lebih setara dalam mendapatkan hak-haknya di bidang sosial maupun budaya. (Nurrahmi : 2009)

Walaupun isu gender telah lama merebak di Indonesia, namun banyak orang yang masih salah mengartikan tentang konsep gender dan kesetaraan gender. Gender sering diartikan dengan seks yang didefinisikan sebagai jenis kelamin yaitu pengkategorian perempuan dan laki-laki. Namun sebenarnya pengertian antara gender dan seks itu berbeda. Seks merupakan pembagian dua jenis kelamin secara biologis. Perbedaan ini sering dikatakan sebagai ketentuan dari Tuhan yang didapat 
secara kodrati, permanen, tidak berubah, tidak dapat dipertukarkan antara kodrat laki-laki dan perempuan.Gender merupakan pembagian sifat yang ada pada manusia, yang penentuannya didasari secara sosial maupun kultural.Sifat ini dapat dipertukarkan antara perempuan dan laki-laki. Pembagian sifat pada manusia terbagi atas feminim yang identik dengan karakteristik perempuan, seperti sifat lembut dan sabar, sedangkan maskulin yang identik dengan karakteristik laki-laki mempunyai sifat yang sebaliknya dengan perempuan. Hal tersebut sesuai dengan yang diutarakan oleh Mansour Fakih (1996) bahwasannya perbedaan biologis merupakan perbedaan jenis kelamin (seks) sementara gender adalah behavioral differencess antara laki-laki dan perempuan yang socially contructed. Gender merupakan perbedaan yang bukan kodrat ciptaan Tuhan namun diciptakan oleh masyarakat (baik laki-laki maupun perempuan) melalui proses sosial dan budaya yang panjang.

Kemudian salah arti lainnya dimana kesetaraan gender seolah-olah dianggap sebagai tindakan atau keinginan menomorsatukan perempuan yang ada di belahan dunia. Padahal hal ini bukan merupakan tujuan dari adanya kesetaraan gender itu sendiri, sebagaimana dijelaskan oleh R. Valentina (2013) bahwa :

"Tujuan kesetaraan gender adalah untuk mewujudkan keadilan gender dalam pemenuhan HAM; menyelenggarakan tindakan khusus sementara guna mempercepat tercapainya persamaan substantif di segala bidang kehidupan; menyelenggarakan upaya pemenuhan hak perempuan atas perlindungan kesehatan reproduksi; menghapus segala bentuk diskriminasi terhadap perempuan; menghapus prasangka, kebiasaan, dan praktik lainnya yang didasarkan atas inferioritas atau superioritas salah satu jenis kelamin atau berdasarkan peranan stereotip perempuan dan laki-laki.” (www.institutperempuan.or.id)

Maka dari itu penulis memandang bahwa kesetaraan gender merupakan suatu norma yang seharusnya dijunjung tinggi oleh masyarakat dengan mengacu pada ajaran agama yang dianut masing-masing. Seperti halnya didalam agama Islam, melalui kedua sumbernya Al Qur'an dan Sunnah, menetapkan posisi dan kedudukan perempuan setara dan seimbang dengan posisi dan kedudukan laki-laki. (Dr. Marzuki, M.Ag., 2008.) Sehingga apabila kita memahami makna gender secara bijaksana dan obyektif berdasarkan dasar hukum dan agama yang dianut, tentu tidak akan memunculkan penolakan terhadap konsep kesetaraan gender itu sendiri karena sesungguhnya kesetaraan gender adalah hal yang positif.

Di Indonesia saat ini, beberapa pihak mengubah makna kesetaraan gender yang sesungguhnya menjadi semakin melenceng dari hal positif. Sebagaimana dilansir oleh salah satu surat kabar yang menyatakan:

"Di Indonesia, sejumlah pegiat kesetaraan gender tampak semakin aneh ketika mereka tidak segan-segan mendukung eksploitasi perempuan berbentuk beauty contest, seperti ajang Miss Universe atau Putri Indonesia. Padahal, ini bertentangan dengan prinsip feminisme diawal kemunculannya. Walau dibungkus dengan brain dan behaviour, tapi kemolekan tubuh dan kecantikan wajah para perempuan yang mengikuti ajang tersebut tetap saja menjadi penilaian utama.Bahkan, anehnya, para aktivis gender ini mendukung sepenuhnya, para perempuan itu mengumbar auratnya." (www.republika.co.id)

Keadaan yang dijelaskan diatas menurut pandangan penulis tentu akan melahirkan stigmastigma negatif masyarakat terhadap konsep kesetaraan gender. Sehingga pada akhirnya muncul stigma kemaksiatan dan kemunkaran dipuja sebagai kebebasan dan kemajuan perempuan. Stigma inilah yang berbanding terbalik dengan tujuan kesetaraan gender pada awalnya. Kesetaraan gender dilahirkan dengan tujuan untuk mengatasi atau mencegah permasalahan di masyarakat seputar isu gender dan kesetaraan gender itu sendiri, bukan untuk menomorsatukan perempuan atau membawa perempuan ke arah negatif. Seperti yang diungkapkan oleh Erna Surjadi dalam bukunya yang 
berjudul Gender Skateboard (2011). "Kesetaraan gender mengangkat persamaan akses, peluang partisipasi, kontrol, dan manfaat yang sama antara laki-laki dan perempuan."

Oleh karena itu, kesadaran tentang isu kesetaraan gender merupakan hal yang perlu diraih baik oleh kaum laki-laki maupun perempuan.

Didalam sebuah penelitian yang dilakukan oleh Dede William kepada kelompok perepuan petani pedesaan di Jambi mengungkapkan bahwa pada awalnya masyarakat setempat sangat risih berbicara dengan kesetaraan gender. Mereka beranggapan bahwa kesetaraan gender adalah hal yang tidak lazim dibicarakan, terlalu vulgar dan mendukung aliran liberalisasi serta sekularitas. Namun dalam beberapa waktu kemudian, kelompok perempuan disana akhirnya menerima bagaimana konsep kesetaraan gender yang sebenarnya. (Dede William, 2006)

Di dalam pekerjaan sosial, terdapat bidang praktik yang menjunjung kesetaraan gender yang disebut dengan pekerja sosial feminis. Teori feminis menjadi paradigma tersendiri yang dikenal dengan namafeminist social work (pekerja sosial feminis). Beranjak dari organisasi sukarela dan aksi masyarakat, perspektif feminis kini merangsek masuk ke bidang-bidang praktik pekerjaan sosial yang lain seperti konseling, terapi kelompok, terapi organisasi, analisis kebijakan sosial, dan penelitian pekerjaan sosial. (Edi Suharto, 2011) Bidang - bidang tersebut adalah lahan bagi pekerja sosial untuk mengedukasi dalam rangka penyadaran masyarakat tentang kesetaraan gender. Kasus-kasus seputar kesetaraan gender di Indonesia memang banyak ditemukan. Sebagai warga negara yang baik tentunya kita tidak perlu berlebihan dalam membela hak perempuan dengan cara propaganda atau kampanye yang melanggar demokrasi. Kesetaraan gender ini dapat dijunjung tinggi melalui perubahan pola pikir masyarakat yang berkembang saat ini.

Mengubah pola pikir masyarakat tentunya harus didasarkan pada pengetahuan masyarakat di daerah itu sendiri. Sehingga pengetahuan masyarakat dapat dijadikan landasan bagaimana dan apa tindakan yang perlu dilakukan selanjutnya untuk menjadikan masyarakat tersebut lebih paham dan peduli pada isu kesetaraan gender. Sebagaimana dikemukakan Arianto Nugroho dalam Kompas, 2011 : 10 bahwa kesetaraan gender tidak terjadi secara ilmiah, terutama di daerah yang memiliki subkultur yang kuat.Dengan demikian, penulis mengemukakan pertanyaan inti yang akan dibahas pada artikel ini yaitu Bagaimana pengetahuan masyarakat desa tentang kesetaraan gender?

\section{KAJIAN PUSTAKA}

\section{A. Konsep Gender}

Kata Gender berasal dari bahasa Inggris berarti “jenis kelamin”. Dalam Webster's NewWorld Dictionary, gender diartikan sebagai perbedaan yang tampak antara laki-laki dan perempuan dilihat dari segi nilai dan tingkah laku. Di dalam Women's Studies Encyclopedia dijelaskan bahwa gender adalah suatu konsep kultural yang berupaya membuat pembedaan (distinction) dalam hal peran, perilaku, mentalitas, dan karakteristik emosional antara laki-laki dan

perempuan yang berkembang dalam masyarakat. Kata gender jika ditinjausecara terminologis merupakan kata serapan yang diambil dari bahasa Inggris.

Kata gender ini jika dilihat posisinya dari segi struktur bahasa (gramatikal) adalah bentuk nomina (noun) yang menunjuk kepada arti jenis kelamin, sex atau disebut dengan al-jins dalam bahasa Arab. Sehingga jika seseorangmenyebut atau bertanya tentang gender maka yang dimaksud adalah jeniskelamin dengan menggunakan pendekatan bahasa. Kata ini masih terbilang

kosa kata baru yang masuk ke dalam khazanah perbendaharaan kata bahasaIndonesia, Istilah ini menjadi sangat lazim digunakan dalam beberapa dekade terakhir. Pengertian gender secara terminologis cukup banyak dikemukakanoleh para feminis dan pemerhati perempuan. Julia Cleves Musse dalambukunya Half the World, Half a Chance mendefinisikan gender sebagai sebuahperingkat peran yang bisa diibaratkan dengan kostum dan topeng pada sebuahacara pertunjukan agar orang lain bisa mengidentifikasi bahwa kita adalah feminim atau maskulin (Rukmina, 2007). 
Menurut BKKBN (2007) Gender adalah perbedaan peran, fungsi, dan tanggungjawab antara laki-laki dan perempuan yang merupakan hasil konstruksi sosial dan dapat berubah sesuai dengan perkembangan jaman.

Sedangkan Depkes RI (2008) menjelaskan bahwa gender adalah pembedaan peran, perilaku, perangai laki-laki dan perempuan oleh budaya/masyarakat melalui interpretasi terhadap perbedaan biologis laki-laki dan perempuan. Jadi gender, tidak diperoleh sejak lahir tapi dikenal melalui proses belajar (sosialisasi) dari masa anak-anak hingga dewasa. Oleh karena itu, gender dapat disesuaikan dan diubah.

\section{B. Kesetaraan dan Ketimpangan Gender}

Kesetaran gender adalah kesetaraan kondisi bagi laki-laki dan perempuan untuk memperoleh kesempatan dan hak-haknya sebagai manusia, agar mampu berperan dan berpartispasi dalam kegiatan politik, ekonomi, sosial budaya, pertahanan dan keamanan nasional, dan kesamaan dalam menikmati hasil pembangunan tersebut Jadi kesetaraan gender adalah menerima dan menilai secara setara (Sufiarti, 2007):

a. Perbedaan antara laki-laki dan perempuan

b. Perbedaan peran yang dipegang oleh laki-laki dan perempuan dalam masyarakat

c. Memahami bahwa perbedaan kondisi hidup laki-laki dan perempuan pada dasarnya karena fungsi melahirkan pada perempuan

d. Menerima perbedaan laki-laki dan perempuan sebagai hikmah

e. Kesetaraan gender tidak sinonim dengan persamaan

f. Kesetaraan gender berarti sederajat dalam keberadaan, sederajat dalam keberdayaan dan keikutsertaan disemua bidang kehidupan domestik dan publik.

Berdasarkan penjelasan tentang kesetaraan gender diatas penulis dapat mengemukakan bahwa kesetaraan gender cenderung bersifat abstrak, karena murni berasal dari pemahaman dan pola pikir manusia itu sendiri. Oleh karena hal itu, seseorang yang benar-benar memahami konsep kesetaraan gender sesuai dengan pengertian sesungguhnya dan menerima segala hal tentang konsep tersebut maka ia akan bertindak sesuai dengan pemahaman yang dimiliki. Inilah yang menjadi kunci agar masyarakat terhindar dari kasus-kasus yang menunjukkan ketimpangan / diskriminasi gender. Diskriminasi gender adalah segala bentuk tindakan yang menunjukkan keadaan atau posisi tidak setara antara laki-laki dan perempuan. Sebagaimana penjelasan BKKBN (2007) bahwa Ketidakadilan atau diskriminasi gender sering terjadi dalam keluargadan masyarakat serta di tempat kerja dalam berbagai bentuk, yaitu

a. Stereotip/Citra Baku, yaitu pelabelan terhadap salah satu jenis kelamin yang seringkali bersifat negatif dan pada umumnya menyebabkan terjadinya ketidakadilan. Misalnya, karena perempuan dianggap ramah, lembut, rapi, maka lebih pantas bekerja sebagai sekretaris, guru Taman Kanakkanak; kaum perempuan ramah dianggap genit; kaum laki-laki ramah dianggapperayu.

b. Subordinasi/Penomorduaan, yaitu adanya anggapan bahwa salah satu jenis kelamin dianggap lebih rendah atau dinomorduakan posisinya dibandingkan dengan jenis kelamin lainnya. Contoh: Sejak dulu, perempuan menguruspekerjaan domestik sehingga perempuan dianggap sebagai "orang rumah" atau "teman yang ada di belakang".

c. Marginalisasi/Peminggiran, adalah kondisi atau proses peminggiran terhadap salah satu jenis kelamin dari arus/pekerjaan utama yang berakibat kemiskinan. Misalnya, perkembangan teknologi menyebabkan apa yang semula dikerjakan secara manual oleh perempuan diambil alih oleh mesin yang pada umumnya dikerjakan oleh laki-laki.

d. Beban Ganda/Double Burden, adalah adanya perlakuan terhadap salah satujenis kelamin dimana yang bersangkutan bekerja jauh lebih banyakdibandingkan dengan jenis kelamin lainnya. 


\section{Konsep Pengetahuan}

Pengetahuan adalah segala sesuatu yang telah diketahui. Adapun caramengetahui sesuatu dapat dilakukan dengan cara mendengar, melihat, merasadan sebagainya yang merupakan bagian dari alat indera manusia (Ahmad,2008).

\section{Tingkat Pengetahuan}

Tingkat pengetahuan menurut Sunaryo (2005) mempunyai 6 tingkatan yaitu :

a. Tahu

Tahu merupakan tingkat pengetahuan yang paling rendah.Tahu artinya dapat mengingat atau mengingat kembali suatu materi yang telah dipelajari sebelumnya.

\section{b. Memahami}

Memahami diartikan suatu kemampuan untuk menjelaskan dan menginterpretasikan dengan benar tentang objek yang diketahui. Seseorang yang telah paham tentang sesuatu harus dapat menjelaskan, memberikan contoh dan menyimpulkan.

c. Penerapan

Yaitu kemampuan untuk menggunakan materi yang telah dipelajari pada situasi dan kondisi nyata atau dapat menggunakan hukum-hukum,rumus, metode dalam situasi nyata.

\section{d. Analisis}

Suatu kemampuan menguraikan objek-objek kedalan bagian-baiankecil, tetapi masih di dalam suatu struktur objek tersebut dan masihterkait satu sama lain. Ukuran kemampuan adalah ia dapat menggambarkan, membuat bagan, membedakan, memisahkan, membuatbagan proses adopsi perilaku dan dapat membedakan pengertian psikologi dengan fisiologi.

e. Sintesis

Sintesis menunjukan kepada suatu kemampuan untukmenghubungkan bagian-bagian didalam suatu bentuk keseluruhan yangbaru atau kemampuan untuk menyusun formulasi baru dari formulasiformulasiyang ada. Ukuran kemampuan adalah ia dapat menyusun, meringkaskan, merencanakan dan menyesuaikan suatu teori atau rumusan yang telah ada.

f. Evaluasi

Evaluasi berkaitan dengan kemampuan untuk mengadakan penilaian terhadap suatu objek. Evaluasi dapat menggunakan kriteria yang telah ada atau disusun sendiri. Pengukuran pengetahuan dapat dilakukan dengan wawancara atauangket yang menanyakan tentang isi materi yang ingin diukur dari subjek penelitian atau responden. Kedalaman pengetahuan yang ingin kita ketahui atau kita ukur dapat kita sesuaikan dengan tingkat-tingkat tersebut diatas(Notoatmodjo, 2007).

\section{Faktor-Faktor Yang Mempengaruhi Pengetahuan}

\section{Pendidikan}

Menurut Notoatmodjo (2005) konsep dasar pendidikan adalah suatu proses belajar yang berarti di dalam pendidikan itu terjadi proses pertumbuhan, perkembangan atau perubahan kearah yang lebih dewasa, lebih baik dan lebih matang pada diri individu, kelompok dan masyarakat. Pendidikan merupakan salah satu faktor yang mempengaruhi pengetahuan adalah suatu proses yang unsurnya terdiri dari masukan(input) yaitu sasaran pendidikan (out put) yaitu suatu bentuk perilaku dan kemampuan dari saran-saran pendidikan. Tujuan pendidikan untuk mengubah perilaku masyarakat yang tidak sehat menjadi sehat. Tujuan tersebut dapat dicapai dengan anggapan bahwa manusia selalu dapat belajaratau berubah, karena manusia selama hidupnya selalu berubah untuk menyesuaikan diri terhadap perubahan lingkungan (Notoadmodjo, 2009).

Jalur pendidikan terdiri atas pendidikan formal, nonformal, dan informal. Jenjang pendidikan formal terdiri atas (Depdiknas, 2004 DalamNotoatmodjo, 2009): 
a. Pendidikan Dasar, Pendidikan dasar berbentuk: Sekolah Dasar (SD) danMadrasah Ibtidaiyah (MI) atau bentuk lain yang sederajat; serta SekolahMenengah Pertama (SMP) dan Madrasah Tsanawiyah (MTs), ataubentuk lain yang sederajat.

b. Pendidikan Menengah, Pendidikan menengah berbentuk: SekolahMenengah Atas (SMA), Madrasah Aliyah (MA), Sekolah MenengahKejuruan (SMK), dan Madrasah Aliyah Kejuruan (MAK), atau bentuklain yang sederajat.

c. Pendidikan Tinggi, Perguruan tinggi dapat berbentuk: akademi, politeknik, sekolah tinggi, institut, atau universitas. Perguruan tinggi berkewajiban menyelenggarakan pendidikan, penelitian, dan pengabdian kepada masyarakat. Perguruan tinggi dapat menyelenggarakan program akademik, profesi, dan/ atau vokasi.

Gangguan terhadap kesehatan juga disebabkan oleh manusia terutama menyangkut pendidikan, pengetahuan dan sikap seseorang dalam menjaga kesehatan apabila tingkat pendidikan seseorang tinggi maka bisamemperbaiki pengetahuan, sikap dan prilaku orang tersebut sehinggamempunyai kesadaran yang tinggi terhadap kesehatan, baik kesehatan pribadi maupun kesehatan keluarga, Pendidikan merupakan kegiatan yang sengaja dilakukan untuk memperoleh hasil berupa pengetahuan, keterampilan dan sikap seseorang (Notoadmodjo, 2009).

\section{Umur}

Umur adalah lama waktu hidup atau ada sejak dilahirkan atau diadakan. Umur juga berpengaruh terhadap psikis seseorang dimana usiamuda sering menimbulkan ketegangan, kebingungan, rasa cemas dan rasatakut sehingga dapat berpengaruh terhadap tingkah lakunya. Biasanyasemakin dewasa maka cenderung semakin menyadari dan mengetahuitentang permasalahan yang sebenarnya. Semakin bertambah umur maka semakin banyak pengalaman yang diperoleh, sehingga seseorang dapatmeningkatkan kematangan mental dan intelektual sehingga dapat membuatkeputusan yang lebih bijaksana dalam bertindak (Hurlock, 2005). yaitu:

Pieter (2010) menguraikan bahwa secara umum masa dewasa dikelompokkan atas tiga bagian

a. Dewasa dini (early adulthood) (21-35 tahun)Masa dewasa dini selalu dianggap sebagai penyesuaian diri terhadap kehidupan dan harapan sosial baru. Kriteria utama periode dewasa dini yaitu interdependen, kesediaan untuk bertanggung jawab dan mempunyai pekerjaan. Interdependen dan tanggung jawab menentukan kondisi kehidupan emosional, sosial dan ekonomi.

b. Dewasa madya (middle adulthood) (35-45 tahun) Kangas dan bradway menyimpulkan bahwa saat periode dewasa madya terdapat kenaikan pada kemampuan intelektual, terutama pada tingkat kecerdasan tinggi. Pria akan menunjukkan perubahan intelektual lebih tinggi dibandingkan wanita. Pria akan menunjukkan peningkatan nilai intelegensi ketika mereka tua.

c. Dewasa akhir (late adulthood) (45-60 tahun) Batasan usia dewasa akhir adalah usia 45-65 tahun dengan perubahan fisik yang menonjol dibandingkan dengan perubahan psikologis. Bagi pria yang memasuki periode ini ditandai dengan memasuki fase klimakterium, sedangkan wanita ditandai dengan fasemenopouse. Ketidakseimbangan fisiologis akan berdampak pada terganggunya keseimbangan emosi seperti stres dan depresi.

\section{Sumber Informasi}

Menurut Notoatmodjo (2005), sumber informasi mempengaruhipengetahuan baik dari media maupun orang-orang dalam terkaitnya dengankelompok manusia memberi kemungkinan untuk dipengaruhi danmempengaruhi anggota-anggota. Seseorang di dalam proses pendidikanjuga memperoleh pengetahuan melalui berbagai macam alat bantu. AlatBantu media akan membantu dalam melakukan penyuluhan. Alat Bantu dapat dibagi dalamtiga macam: 


\section{a. Media Cetak}

Yaitu sarana komunikasi untuk menyampaikan pesan kesehatan dengan variasi seperti: (1) Booklet. Suatu media untuk menyampaikan pesan-pesan kesehatan dalam bentuk tulisan maupun gambar. (2) Leaflet. Bentuk penyampaian informasi melalui lebaran yang dilipat. informasi dapat dalam bentuk kalimat maupun dalam bentuk gambar. (3)Selebaran. (4) Lembar balik (Flip Chart). Bentuk penyampaian pesan atau informasi-informasi dalam bentuk lembar balik di manatiap lembar berisi gambaran peragaan dan di baliknya berisi kalimat yangberkaitan dengan gambar tersebut. (5) Rubik atau tulisan-tulisan pada surat kabar atau majalah yang berkaitan dengan topik terkait. (6) Foster. Bentuk media cetak berisi pesan-pesan atau informasi kesehatan yangbiasanya ditempel di tembok-tembok, di tempat-tempat umum atau dikendaraan umum.

\section{b. Media Elektronika}

Media sarana komunikasi merupakan sarana komunikasi denganmenggunakan elektronik terdiri dari televisi, radio, video, dan lain-lain.Untuk menyampaikan pesan-pesan atau informasi

\section{c. Media Papan}

Papan yang dipasang di tempat-tempat umum yang diisi dengan pesan-pesan atau informasi kesehatan. Informasi adalah keterangan pemberitahuan kabar berita tentangsuatu media dan alat (sarana) komunikasi seperti Koran, majalah, radio, televisi, poster, spanduk, internet. Media komunikasi adalah media yangdigunakan pembaca untuk mendapatkan informasi sesuatu atau hal tentangpengetahuan.

\section{PEMBAHASAN \\ Pengetahuan Masyarakat Desa tentang Kesetaraan Gender}

Seperti yang telah dijelaskan sebelumnya bahwa kesetaraan gender berbicara tentang penerimaan dan penilaian seseorang terhadap perbedaan antara laki-laki dan perempuan. Dengan demikian pengetahuan masyarakat desa tentang kesetraaan gender menggambarkan bagaimana masyarakat menerima dan menilai dua jenis kelamin yang berbeda kedalam kedudukan dan posisi setara dalam berbagai aspek kehidupan.

Berdasarkan tingkat pengetahuan, maka pengetahuan masyarakat desa dapat digolongkan kedalam beberapa kategori.Namun, penulis memandang hal ini secara nyata tidak menentukan tingkat pengetahuan yang dimiliki masyarakat tentang kesetaraan gender.Salah satu keadaan pada kehidupan nyata misalnya pada keluarga petani di suatu desa.Suami dan istri membagi tugas secara adil dalam hal pekerjaan tanpa memandang pekerjaan tersebut cenderung harus dilakukan oleh perempuan atau laki-laki. Suami dan istri pada keluarga petani saling bekerja sama ketika mereka sedang berada di sawah. Sehingga perempuan yang melekat dengan kata lemah lembut, gemulai, dan tidak mampu melakukan pekerjaan berat semuanya tidak berlaku lagi ketika sedang bekerja di sawah.Pembagianpembagian kerja antara laki-laki dan perempuan dilakukan atas kesadaran masing-masing sehingga tidak ada pihak yang dirugikan atau disampingkan. Hal yang demikian menggambarkan bahwa keluarga petani di desa tersebut sesungguhya telah menerapkan konsep kesetaraan gender pada kehidupan keseharian mereka di sawah. Akan tetapi kondisi tersebut belum tentu mengartikan bahwa mereka telah paham apa makna dari kesetaraan gender itu sendiri.

Beralih dari konsep yang pertama mengenai tingkatan pengetahuan, ada pula faktor-faktor yang mempengaruhi pengetahuan seseorang seperti yang telah dijelaskan pada tinjauan pustaka, diantaranya : pendidikan, umur, dan sumber informasi. aspek-aspek tersebut dijadikan kategori oleh penulis dalam melakukan analisis bagaimana pengetahuan masyarakat desa tentang kesetaraan gender. 


\section{1) Pendidikan}

Pendidikan merupakan faktor utama yang menentukan pengetahuan seseorang.Seperti yang dijelaskan pada tinjauan pustaka, manusia selama hidupnya selalu berubah untuk menyesuaikan diri terhadap lingkungan.Dengan demikian pengetahuan seseorang dapat dibedakan berdasarkan tingkat pendidikan yang telah ditempuh.Jalur pendidikan dapat ditempuh melalui pendidikan formal dan non formal pada fasilitas-fasilitas yang tersedia.Namun, hal yang menjadi titik kesulitan utama masyarakat desa ialah kekurangan fasilitas pendidikan terdekat.Sehingga sebagian besar masyarakat desa yang mengalami kesulitan dalam biaya transportasi tidak meneruskan sekolah ke jenjang yang lebih tinggi. Akhirnya hingga saat ini masih banyak masyarakat desa yang memiliki pendidikan lulusan SD terutama penduduk usia dewasa akhir dan lansia. Selain karena faktor jarak, adapula faktor ekonomi yang menyebabkan rendahnya tingkat pendidikan masyarakat desa yang umumnya bermatapencaharian sebagai petani.Seperti yang telah diungkapkan pada tinjauan pustaka bahwa masyarakat kota pada awalnya merupakan masyarakat desa. Oleh karena itu pendidikan di pedesaan tidak diam di tempat melainkan terus berkembang seiring perkembangan zaman.Sehingga wajar bila pada saat ini sebagian kecil penduduk di desa sudah memiliki ijazah perguruan tinggi.Secara linear, hal ini juga berhubungan dengan pengetahuan masyarakat desa tentang kesetaraan gender.Didalam tinjauan pustaka disebutkan bahwa semakin tinggi tingkat pendidikan seseorang maka semakin tinggi pula pengetahuan orang tersebut. Oleh karena itu tidak semua warga desa yang belum memahami konsep gender dan kesetaraan gender. Akan tetapi bergantung pada tingkat pendidikan seluruh penduduk yang ada di desa tersebut. Sehingga penulis mengasumsikan jika tingkat pendidikan penduduk di suatu desa sangat rendah atau termasuk desa tertinggal maka pengetahuan masyarakat tentang kesetaraan genderpun akan rendah. Masyarakat yang tidak memahami konsep gender dan kesetaraan gender kemudian akan menganggapnya sebagai salah satu hal yang tabu. Oleh karena itu, desa dengan tingkat pendidikan penduduk yang rendah berpotensi besar bagi pekerja sosial untuk diberikan intervensi.

\section{2) Umur}

Semakin bertambah umur maka semakin banyak pengalaman yang diperoleh, sehingga seseorang dapat meningkatkan kematangan mental dan intelektual sehingga dapat membuat keputusan yang lebih bijaksana dalam bertindak (Hurlock, 2005).

Berdasarkan penjelasan tersebut, maka diperoleh gambaran bahwa pengetahuan seseorang akan bertambah seiring bertambahnya usia atau pengalaman seseorang tersebut. Oleh karena itu, semakin tua umur seseorang maka seharusnya ia semakin mengerti tentang konsep kesetaraan gender. Jika dihubungkan dengan tingkat pendidikan di pedesaan yang rata-rata penduduk berpendidikan rendah adalah ia yang berusia tua, maka pengetahuan masyarakat desa tentang kesetaraan genderpun akan rendah pada penduduk dengan usia tua. Sehingga penulis mengasumsikan bahwa intervensi pekerjaan sosial perlu diberikan kepada usia penduduk desa dengan tingkat pendidikan rendah dan kategori usia yang paling membutuhkan. Kategori usia yang paling membutuhkan ialah usia yang rawan berhadapan dengan kasus-kasus ketidakadilan gender diantaranya dewasa dini dan dewasa madya.

\section{3) Sumber Informasi}

Sumber informasi baik dari media maupun orang-orang di sekitar akan mempengaruhi pengetahuan yang dimiliki oleh seseorang. Dengan demikian diperoleh analogi jika sumber informasi tentang kesetaraan gender di suatu daerah jumlahnya terbatas maka pengetahuan yang dimiliki oleh masyarakat setempat tentang kesetaraan genderpun akan kurang. Namun, sumber informasi juga dapat menjadi penyebab munculnya kekeliruan paham masyarakat tentang kesetaraan gender. Oleh karena itu diperlukan media dan cara penyampaian yang tepat untuk mengubah paham masyarakat dari yang asalnya tidak tahu menjadi tahu dan asalnya berfikir negatif menjadi berfikir positif.Hal ini 
dapat terjadi pada masyarakat pedesaan dengan kategori daerah terpencil, tingkat ekonomi rendah atau pendidikan rendah, dan tingkatan religius yang kental (tinggi).

\section{PENUTUP \\ Kesimpulan}

Kesadaran masyarakat tentang kesetaraan gender berawal dari pengetahuan yang dimiliki oleh masyarakat itu sendiri. Pengetahuan yang positif tentang kesetaraan gender akan membawa manfaat yang banyak bagi setiap perempuan dan laki-laki dalam menjalani tugas-tugas kehidupan. Sedangkan kekeliruan atau ketidakpahaman masyarakat mengenai makna kesetaraan gender dapat menjadi penyebab bertambahnya kasus-kasus kesetaraan gender yang terjadi pada masyarakat Indonesia baik pada laki-laki maupun perempuan. Kasus KDRT, perceraian yang semakin marak terjadi pada awalnya disebabkan oleh disfungsi pembagian kerja, peran, hak, dan pengambilan keputusan antara laki-laki dan perempuan. Sehingga pemahaman tentang kesetaraan gender tujuan utamanya adalah untuk mengurangi permasalahan-permasalahan yang terjadi dalam kehidupan rumah tangga dan mendorong terbentuknya keluarga-keluarga yang harmonis dan sejahtera.Dengan demikian bukan hanya perempuan yangperlu memahami kesetaraan gender, tetapi justru laki-laki.Secara fakta tindakan kekerasan dalam rumahtangga sebagian besar dialami oleh kaum perempuan.Dengan demikian yang perlu mendapatkan perubahan sikap ialah orang yang melakukan tindakan kekerasan tersebut.Memberikan pemahaman hingga berwujud menjadi kesadaran dan perubahan sikap merupakan bagian dari tugas fungsi pekerjaan sosial sebagai pembawa perubahan sekaligus problem solver. Dalam hal ini intervensi pekerjaan sosial dapat berbentuk tiga upaya yaitu, engage, educate, empower.

Engage diantaranya merupakan upaya pekerjaan sosial untuk menghubungkan korbankorban ketidakadilan gender kepada pihak atau lembaga yang memiliki kewenangan. Educate yaitu upaya memberikan pemahaman kesetaraan gender kepada masyarakat terutama kelompok-kelompok yang membutuhkan. Sedangkan empower merupakan upaya memberikan kemauan dan kemampuan untuk bertindak kepada kelompok yang dianggap paling membutuhkan. Didasarkan pada tingkatan pengetahuan, masyarakat desa adalah sasaran yang paling membutuhkan edukasi mengenai kesetaraan gender.Secara inti, edukasi tersebut diberikan untuk mengurangi ketidakpahaman dan kekeliruan pemikiran masyarakat mengenai kesetaraan gender.Kemudian penulis menganalisis secara sederhana masyarakat pedesaan berdasarkan faktor-faktor yang mempengaruhi pengetahuan.Faktor-faktor tersebut diantaranya pendidikan, umur, dan sumber informasi.

Berdasarkan pendidikan, kelompok penduduk dengan tingkat pendidikan rendah berpotensi besar memiliki pengetahuan yang rendah tentang kesetaraan gender. Berdasarkan usia, pengetahuan tentang kesetaraan gender semakin meningkat seiring bertambahnya usia dan bertambahnya pendidikan seseorang. Namun kategori usia yang paling membutuhkan edukasi ialah mereka yang rawan berhadapan dengan kasus ketidakadilan gender yaitu penduduk yang telah berrumah tangga diantaranya usia dewasa dini dan dewasa madya. Berdasarkan sumber informasi, pengetahuan masyarakat desa tentang kesetaraan gender akan rendah pada daerah yang memiliki kekurangan sumber informasi mengenai hal terkait. Sumber informasi juga merupakan faktor penyebab penting ketidakpahaman dan kekeliruan masyarakat pedesaan memaknakan kesetaraan gender.Oleh karena itu tugas pekerja sosial feminis yaitu memberikan pemahaman yang sesuai kepada kelompok yang tepat melalui media penyampaian yang tepat.Karakteristik masyarakat pedesaan menjadi dasar utama yang harus dipertimbangkan oleh pekerja sosial dalam melakukan praktik pelayanan.

Inti dari artikel ini bahwa masyarakat khususnya masyarakat pedesaan memerlukan tambahan pengetahuan tentang kesetaraan gender. Pemahaman tentang kesetaraan gender yang positif pada masyarakat memiliki banyak manfaatnya dalam kehidupan terutama untuk mengurangi kasus-kasus ketidakadilan gender dan permasalahan rumah tangga. Adapun yang menjadi dasar bagi pekerja sosial 
dalam melakukan intervensi ialah pendidikan, umur, dan sumber informasi di suatu daerah atau masyarakat tersebut.

\section{DAFTAR PUSTAKA}

\section{Buku dan e-Book}

Surjadi, Erna. 2011. Gender Skateboard: Kekuatan spirit Gender dalam Rumah Tangga. Jakarta : Pustaka Harapan.

Fakih, Mansoer.1997. Analisis Gender dan Transformasi Sosial. Yogyakarta: Pustaka Pelajar. Rahmawati, Ika. 2003. Modul Analisis Gender. Jakarta: The Asia Foundation.

Notoatmodjo S. (2007). Kesehatan Masyarakat, Ilmu dan Seni. Rineka Cipta, Jakarta.

Depkes RI, (2008), Pedoman Pelaksanaan Kegiatan KIE Kesehatan Reproduksi Untuk Petugas Kesehatan Di Tingkat Pelayanan Dasar, Depkes RI,Jakarta.

Dede William, (2006), Gender Bukan Tabu, Catatan Perjalanan Fasilitasi Kelompok Perempuan Di Jambi, CIFOR, Bogor, Indonesia.

BKKBN, (2007), Program Pembinaan Jarak Jauh, Pangarusutamaan Gender (PJJ-PUG), Konsep Dan Teori Gender, BKKBN, Jakarta.

\section{Jurnal, Hasil Penelitian, dan Skripsi}

Asyhari. 2009. Kesetaraan Gender Menurut Nasaruddin Umar dan Ratna Megawangi (Skripsi).

Rukmina, (2007), Fenomena Bias Gender Dalam Pendidikan Islam, Jurnal, Vol.4, Jakarta.

Sufiarti, (2007), Laporan Penelitian Persepsi Perempuan Berkarir Di Lingkungan UPI Tentang Konsep Kesetaraan Gender, Jurnal, Jakarta.

\section{Website dan Blog}

http://syafroafni.wordpress.com/2013/01/12/masyarakat-desa-dan-masyarakat-kota/ diunduh pada Selasa, 4 November 2014 pukul 04.10 WIB.

www.institutperempuan.or.id

(www.republika.co.id) 